\title{
NEW METHOD FOR EVALUATION OF CUTANEOUS SENSIBILITY IN DIABETIC FEET. PRELIMINARY REPORT
}

\author{
Marcus Castro Ferreira, Leandro Rodrigues and Klaus Fels
}

FERREIRA MC et al. New method for evaluation of cutaneous sensibility in diabetic feet. Preliminary report. Rev. Hosp. Clín. Fac. Med. S. Paulo 59(5):286-290, 2004.

Diabetic neuropathy is an important complication of the disease, responsible for ulceration and amputation of the foot. Prevention of these problems is difficult mainly because there is no method to correctly access sensibility on the skin of the foot.

The introduction of the Pressure-Specified Sensory Device (PSSD ${ }^{\mathrm{TM}}$ ) in the last decade made possible the measurement of pressure thresholds sensed by the patient, such as touch, both static and in movement, on a continuous scale.

This paper is the first in Brazil to report the use of this device to measure cutaneous sensibility in 3 areas of the foot: the hallux pulp, the calcaneus, and the dorsum, which are territories of the tibial and fibular nerves.

METHOD: Non-diabetic patients were measured as controls, and 2 groups of diabetic patients - with and without ulcers - were compared. The PSSD ${ }^{\mathrm{TM}}$ was used to test the 3 areas described above. The following were evaluated: 1 PS (1point static), 1 PD (1-point dynamic), 2 PS (2-points static), 2 PD (2-points dynamic).

RESULTS: The diabetic group had poorer sensibility compared to controls and diabetics with ulcers had poorer sensibility when compared to diabetics without ulcers.

The differences were statistically significant $(P<.001)$.

CONCLUSION: Due to the small number of patients compared, the results should be taken as a preliminary report.

\section{KEY WORDS: Diabetic neuropathies. Diabetes mellitus. Diabetic foot.}

Changes in cutaneous sensibility of lower extremities present in diabetic neuropathy play an important role in the incidence of complications and on the overall morbidity of diabetes.

About $15 \%$ of the diabetic population will develop ulcerations on their lower extremities, usually complicated by infection and a slower healing rate. This eventually leads to the amputation of lower extremities. ${ }^{1}$ Moreover, amputations are more frequent in diabetic patients than in the non-diabetic population. $^{2}$

The explanation of how diabetes causes nerve injury is not completely clear. Contributing factors include metabolic injury due to the hyperglycemia, immunological factors, and microvascular damage to the blood supply of the nerve. . $^{3-5}$

A recent theory associates these "intrinsic" causes to an "extrinsic" factor, namely the chronic compression sustained by the swollen nerve when

From the Division of Plastic Surgery, Hospital das Clínicas, Faculty of Medicine, University of São Paulo, São Paulo/SP, Brazil.

E-mail: rodriguesle@ hotmail.com Received for publication on November 14, 2003. it transits through anatomic tunnels, like the tarsal tunnel. ${ }^{6,8}$

Diabetic neuropathy has been considered irreversible, with no known treatment available. ${ }^{9}$ However, measurement of the degree of sensory impairment is paramount for the establishment of preventive measures to avoid ulceration. Moreover, although neuropathy is bilateral, the symptoms may affect the two feet to different degrees.

Dellon et al. ${ }^{10,11}$ made the proposal to use surgical release of tarsal tunnel to decompress the tibial nerve in the diabetic who has neuropathy symp- 
toms and evidence of sensory nerve compression, adding thereby another important need for a more precise evaluation of the sensory deficit.

Measurement of cutaneous sensibility has been undertaken by instrumentation that assesses temperature threshold, but the sensation of touch is more important on the foot in order to prevent ulceration.

Pain and temperature are conducted by thin unmyelinated (A delta fibers), whereas sensation of touch is conducted by A beta fibers, which can be divided into slowly and quickly adapting fibers that are related to specific receptors.

On the skin, continuous pressure, which stimulates Ruffini and Merkel terminations, is transmitted by slowadapting fibers. Vibration, on the other hand, exerts a quick stimulus to the Meissner and Paccini receptors, which is transmitted by fast-adapting fibers and is felt by the patient as moving touch. ${ }^{9}$ This stimulus is a wave form and will stimulate the peroneal nerve on the dorsum of the foot, and the tibial nerve on the plantar aspect of the foot at the same time.

Perception of touch was first measured using pressure of Von Frey hair filaments, but this approach has been replaced worldwide by the Semmes Weinstein nylon monofilaments. They are rods of different sizes and are useful for determining the threshold of pressure, represented by a certain diameter, below which the patient does not feel touch. This touch stimulus is perceived only by the piece of skin being stimulated, in contrast to vibration.

Semmes-Weinstein filaments are part of most endocrinologists' armamentarium, and the specific size that gives a force of $10 \mathrm{~g}$ is considered as the upper limit of a sensible foot for diabetics. This filament has a logarithmic value of 5.07. Semmes-Weinstein filaments, however, do not supply a continuous graduation and so the evaluation is less precise; they just give an estimate of a range.

Moving touch may be assessed by a vibrometer, but the device is not regularly employed by the average physician. ${ }^{9}$

An important contribution was the Disk-Criminator $^{\mathrm{TM}}$ (Fig. 1) to evaluate the so-called 2-point discrimination, routinely used in nerve injuries to the hand but only recently applied to the foot of diabetic patients. ${ }^{12}$

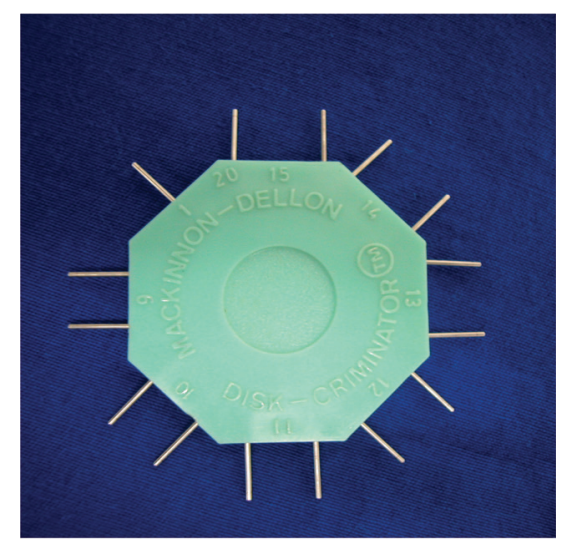

Figure 1 - Disk-Criminator ${ }^{\mathrm{TM}}$

The test measures the minimum distance of separation in $\mathrm{mm}$ that the patient reports feeling the 2 points of the instrument touching the skin. ${ }^{13}$ It is also useful for predicting the severity of the neuropathy, since it assesses the density of innervations on that specific area. However, different examiners may apply it to the skin at different pressures, resulting in ambiguity.

In the 1990s, Dellon proposed a new device, the Pressure-Specified

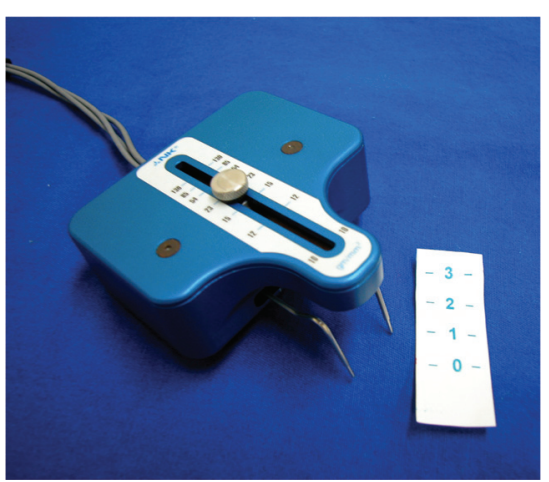

Figure 2 - Pressure-Specified Sensory Device $\left(\mathrm{PSSD}^{\mathrm{TM}}\right)$ transducer
Sensory Device ${ }^{\mathrm{TM}}$ (PSSD) (Fig. 2) that could gather information about static and moving touch in a continuous form by using a computer. This device specified the pressure at which 1 point would be distinguished from 2 points, resolving the conflicts mentioned above.

Associating the concept of 2-point discrimination as given by the DiskCriminator with the $\mathrm{PSSD}^{\mathrm{TM}}$, both thresholds of touch and density of fibers could be more precisely evaluated.

The PSSD ${ }^{\mathrm{TM}}$ has been used to assess sensation of many areas of the body, especially in hand surgery. ${ }^{14} \mathrm{We}$ introduced the device in the Hospital das Clínicas-FMUSP in 1999, and since then it has been used to study the sensibility of the skin on the face, hand, and on the breast after reduction mammaplasty. ${ }^{15}$

Measuring sensation on the feet of diabetic patients seemed a natural extension of that research. A first project was planned in order to evaluate the sensibility on the foot among nondiabetic patients, diabetics without ulceration, and those with ulcers on the lower extremity.

The purpose of this paper is to report the preliminary findings.

\section{METHOD}

We evaluated sensibility on the feet of 28 patients. The mean age was 54 years (38 to 62 ). Seventeen were women and 11 men.

Ten patients were used as controls, since they were not considered to be diabetic (they had normal blood sugar levels, and they presented no symptoms).

Ten other patients were diabetic, controlled by medication, and never had an ulceration on the lower extremity.

Eight patients were diabetic and exhibited chronic ulcer on only one foot. 


\section{Evaluation of sensibility}

Sensibility was measured using the $\operatorname{PSSD}^{\mathrm{TM}}$ (Fig. 2) and the Diskcriminator $^{\mathrm{TM}}$ (Fig. 1) as suggested by Seiler et al. ${ }^{12}$ The minimum distance of 2 points perceived by the patient is assessed using the Disk-Criminator.

The PSSD ${ }^{\mathrm{TM}}$ consists of a structure with parallel metallic prongs that can be positioned at the specific distance in millimeters. The patient is put in a comfortable reclining position and asked to report (pressing a button) when feeling the pressure of either 1 point or with 2 points exerted by the examiner's hand. The results are integrated by a computer. The distance the patient can first discriminate 2 discrete points with the Disk-Criminator ${ }^{\mathrm{TM}}$ is taken as the distance to begin testing with the $\mathrm{PSSD}^{\mathrm{TM}}$.

Therefore, 6 thresholds can be obtained in a specific area of the foot: 2 point minimum distance in $\mathrm{mm}$, both static and moving; 1-point pressure, static and moving $\left(\mathrm{g} / \mathrm{mm}^{2}\right)$ and 2-point pressure threshold, both static and moving (Table 1).

Table 1 - Pressure-Specified Sensory Device $\left(\mathrm{PSSD}^{\mathrm{TM}}\right)$ results $\left(\mathrm{g} / \mathrm{mm}^{2}\right)$.

\begin{tabular}{llrrr}
\hline PSSD & & Hallux & Dorsum & Calcaneus \\
\hline 1PS & ND & 1.3 & 2.1 & 1.3 \\
& D1 & 35.1 & 20.3 & 30.5 \\
& D2 & 78.0 & 37.9 & 47.7 \\
& & & & \\
1PD & ND & 1.2 & 2.0 & 1.2 \\
& D1 & 21.0 & 13.5 & 20.4 \\
& D2 & 59.9 & 31.0 & 33.3 \\
& & & & \\
2PS & ND & 15.8 & 16.5 & 17.2 \\
& D1 & 23.2 & 30.0 & 20.6 \\
& D2 & 43.4 & 53.1 & 30.0 \\
& & & & \\
2PD & ND & 8.9 & 9.8 & 9.4 \\
& D1 & 21.2 & 27.7 & 19.4 \\
& D2 & 41.0 & 39.0 & 32.1 \\
\hline
\end{tabular}

1PS: 1 Point Static

1PD: 1 Point Dinamic

2PS: 2 Point Static

2PS: 2 Point Dinamic

ND: Nondiabetics

D1: Diabetics without ulceration

D2: Diabetics with ulceration
The tests were done in 3 areas (Fig.

3, Fig. 4, Fig. 5):

a) hallux pulp, territory of the medial plantar branch of the posterior tibial nerve.

b) calcaneus, over the medial aspect of the foot to avoid the thick epidermis, territory of the calcaneal branch of the tibial nerve.

c) first commissure on the dorsum of the foot ${ }^{-}$area of the deep branch of the fibular nerve.

The results of the test were submitted to statistical analysis by the ANOVA method: control versus diabetic without ulcer, control versus diabetic with ulcer, and between the 2 groups of diabetics.
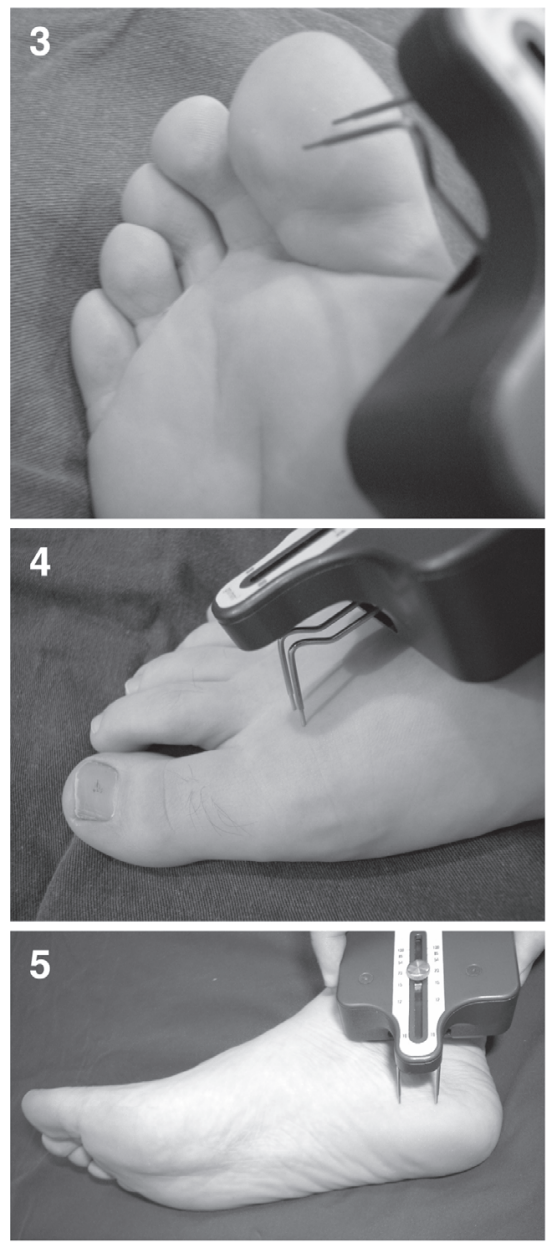

Figures 3, 4, 5 - Demonstration of measurements in the three different areas: hallux pulp, first comissure at the feet dorsum and medial calcaneus (APUD: Dellon AL, Somatosensory testing and rehabilitation. Baltimore Institute for peripheral nerve surgery, 2002)
The significance level was set at $P$ $<.001$.

\section{RESULTS}

The results obtained with the 2point discrimination are shown on Table 2. The PSSD results are shown on Table 1.

Table 2 - Disk-criminator ${ }^{\mathrm{TM}}$ results (mm).

\begin{tabular}{llrrc}
\hline Disk & & Hallux & Dorsum & Calcaneus \\
\hline Static & ND & 8.4 & 9.1 & 8.3 \\
& D1 & 8.2 & 8.1 & 7.2 \\
& D2 & 14.3 & 13.5 & 9.6 \\
Dinamic & ND & 7.2 & 8.1 & 7.3 \\
& D1 & 7.2 & 6.3 & 5.1 \\
& D2 & 13.7 & 13.3 & 8.9 \\
\hline
\end{tabular}

ND: Nondiabetics

D1: Diabetics without ulceration

D2: Diabetics with ulceration

Discrimination in nondiabetic patients (controls) was about $8 \mathrm{~mm}$ in plantar areas, similar to the findings in diabetic group without ulcer, but lower than in the group with ulcers, which had discriminations of about $14 \mathrm{~mm}$.

The mean data with the PSSD on the plantar area of the hallux for 1 static and moving point were: normal$1.29 \mathrm{~g} / \mathrm{mm}^{2}$ and $1.20 \mathrm{~g} / \mathrm{mm}^{2}$; diabetic, no ulcer-35.10 g/ $/ \mathrm{mm}^{2}$ and $21 \mathrm{~g} / \mathrm{mm}^{2}$; and for diabetic, with ulcer-78.04 g/ $\mathrm{mm}^{2}$ and $59.94 \mathrm{~g} / \mathrm{mm}^{2}$.

Data for 2-point thresholds for static and moving points were: normal$15.82 \mathrm{~g} / \mathrm{mm}^{2}$ and $8.90 \mathrm{~g} / \mathrm{mm}^{2}$; diabetic, no ulcer- $23.26 \mathrm{~g} / \mathrm{mm}^{2}$ and 21.19 $\mathrm{g} / \mathrm{mm}^{2}$; and diabetic with ulcer ${ }^{-} 43.41$ $\mathrm{g} / \mathrm{mm}^{2}$ and $40.99 \mathrm{~g} / \mathrm{mm}^{2}$.

Comparisons of groups had statistical significance with $P<.001$.

\section{DISCUSSION}

Evaluation of sensibility on the feet of diabetic patients is of para- 
mount importance in order to provide proper identification of the group with neuropathy and to establish prevention of ulceration for those at risk.

Measurement of touch perception as conferred by receptors to pressure and vibration has been traditionally performed by Semmes-Weinstein mono-filaments and vibrometers, but the results are not precise enough to determine the degree of neuropathy or to diagnose those with additional nerve compression.

The PSSD ${ }^{\mathrm{TM}}$ represents, associated with the assessment of 2-point discrimination, a modern method for evaluating sensibility in diabetics.

The method is subjective, since the patient must report whether or not the pressure is felt, but it is more reliable than the previously available methods and gives data in a continuous range.
The present paper is the first communication of the use of this device in Brazil to assess sensibility on diabetic feet; consequently, the results should be taken as a preliminary report.

In the first group of patients, who were not diabetic, the data can be considered as normative and is comparable to that published for Caucasians from the U.S.A. in 1996. ${ }^{16,17}$ Therefore, this data was used as the control group for the data obtained from the diabetic population.

It was clear that average 2-point discrimination distance for the control group was about $8 \mathrm{~mm}$, a value considered to be normal for fiber density on those areas in patients above the age of 45 years.

Some patients of the diabetic group remained at this level, but clearly, patients with ulcers had higher numbers, indicating chronic loss of axons.

PSSD data, both static and moving, 1- or 2-point touch evaluations, showed increased thresholds in the diabetic population when compared with the control group, and within the diabetic group, thresholds were even higher in patients who had ulcerations, and differences in both were statistically significant, $\mathrm{P}<.001$.

The abnormal values found in our diabetics with and without ulcers were similar to those reported by Tassler and Dellon in $1995 .^{16}$

The tests, as presented here, will represent an important tool to help doctors achieve better control with diabetic patients and establish preventive measures that will improve quality of life for their patients.

\section{RESUMO}

FERREIRA MC e col. Novo método para avaliação da sensibilidade cutânea do pé diabético. Relato preliminar. Rev. Hosp. Clín. Fac. Med. S. Paulo 59(5):286-290, 2004.

A neuropatia diabética é uma complicação importante do Diabetes melitus, responsável por ulcerações e amputações de membros inferiores.

A prevenção desses problemas é difícil principalmente pela ausência de métodos que avaliem de forma precisa a sensibilidade cutânea dos pés.

A introdução do PSSD ${ }^{\mathrm{TM}}$ (PressureSpecified Sensory Device) na década passada tornou possível a medição dos limiares cutâneos de pressão. Estes são sentidos como estímulos táteis tanto estáticos como dinâmicos.

Este artigo é o primeiro no Brasil a relatar o uso do PSSD $^{\mathrm{TM}}$ para avaliar 3 áreas dos pés: polpa do hallux, calcâneo e dorso do pé, territórios de inervação dos nervos tibial e fibular.

MÉTODO: Pacientes não diabéticos foram utilizados como grupo controle e dois grupos de pacientes diabéticos - sem úlcera e com úlcera - foram analisados. O PSSD ${ }^{\mathrm{TM}}$ foi utilizado em 3 modalidades: 1 PS (1 Ponto Estático), 1 PD (1 Ponto dinâmico), 2
PS ( 2 pontos estáticos), 2 PD (2 Pontos Dinâmicos). Foram avaliadas as 3 áreas citadas acima.

RESULTADOS: Foi observada pior sensibilidade em pacientes diabéticos, especialmente no grupo de pacientes com úlceras de membros inferiores. As diferenças foram estatisticamente significantes $(\mathrm{p}<0,001)$.

CONCLUSÃO: Devido ao pequeno número de pacientes os resultados devem ser considerados como relato preliminar.

UNITERMOS: Neuropatias diabéticas. Diabetes mellitus. Pé diabético.

\section{REFERENCES}

1. Watkins PJ. Natural history of diabetic neuropathies. Q J Med 1990;77:1209-18.

2. Moss SE, Klein R, and Klein BE. The 14-year incidence of lowerextremity amputation in a diabetic population. Diabetes Care, 1999;22:951-9.
3. Cameron NE, and Cotter, MA. Metabolic and vascular factors in the pathogenesis of diabetic neuropathy. Diabetes 1997,46(suppl. 2):S31-S37.

4. Diabetic polyneuropathy in controlled clinical trials: consensus report of peripheral nerve society. Ann Neurol 1995,38:478-82. 
New method for evaluation of cutaneous sensibility in diabetic feet Ferreira MC et al.

5. Tuck RR, Schmelzer JD, and Low PA. Endoneurial blood flow and oxygen tension in the sciatic nerves of rats with experimental diabetic neuropathy. Brain 1984;107:935-50.

6. Dellon AL, Mackinnon SE, and Seiler WA. Susceptibility of the diabetic nerve to chronic compression. Ann Plast Surg 1988;20:117-9.

7. Dellon AL - Optimism in diabetic neuropathy. Ann Plast Surg 1988;20:103-5.

8. Kale B, Yüksel F, Celiköz B, Sirvanci S, Ergun O, Arbak S. Effect of various nerve decompression procedures on the functions of distal limbs in streptozotocin-induced diabetic rats: further optimism in diabetic neuropathy. Plast Reconstr Surg $2003 ; 111: 2265-72$

9. Dellon AL. Somatosensory testing and rehabilitation. Baltimore Institute for peripheral nerve surgery, 2002.

10. Dellon AL. Treatment of symptomatic diabetic neuropathy by surgical decompression in multiple peripheral nerves. Plast Reconstr Surg 1992;89:689-97.

11. Aszmann OC, Kress KM, and Dellon AL. Results of nerve decompression of peripheral nerves in diabetics: a prospective, blinded study. Plast Reconstr Surg, 2000;106:816-22.
REV. HOSP. CLÍN. FAC. MED. S. PAULO 59(5):286-290, 2004

12. Seiler DK, Barret S, Dellon AL. The Interpretation Guide for Neurosensory and Motor Testing. $1^{\text {st }}$ ed. Institute for Peripheral Nerve Surgery. 2002.

13. Mackinnon SE, Dellon AL. Surgery of the peripheral nerve. Thieme Publishers, 1988.

14. Dellon ES, Keller KM, Moratz V, Dellon AL. Validation of cutaneous pressure threshold measurements for the evaluation of hand function. Ann Plast Surg 1997;38:485-92.

15. Ferreira MC, Costa MP, Cunha MS, Sakae E, Fels KW. Sensibility of the breast after reduction mammaplasty. Ann Plast Surg 2003,51:1-5.

16. Tassler PL, Dellon AL. Cutaneous pressure thresholds in ulcerated and non-ulcerated diabetic feet, measured with the PressureSpecified Sensory Device. J Am Pod Med Assoc 1995;85:67984

17. Tassler PL, Dellon AL. Pressure perception in the normal lower extremities and tarsal tunnel syndrome. Muscle and Nerve 1996;19:285-9 